\title{
THE SOUND SYSTEMS OF ENGLISH AND SLOVENE COMPARED: A DISTINCTIVE FEATURE ANALYSIS ${ }^{1}$
}

This is an attempt to show how the phonetic properties of sounds are put to work in Slovene and in English. We want to find out the number and the type of distinctive contrasts employed in the two languages and how these contrasts are structured. We classified the sound systems of the two languages with the same distinctive features as far as this is feasible, while at the same time aiming at a realistic phonetic and phonological representation of the two sound inventories. Together with the phonological rules of the two languages, which are not worked out in the present article, this analysis can serve as a basis for a contrastive English-Slovene and Slovene-English sound analysis.

To my knowledge there exists only one distinctive feature analysis of the Slovene sound system, based on Jakobson, Fant and Halle (1952) carried out by $R$. Lenček (1966, 7- vowels only; 1982, 163 - vowels, 171 - consonants). Toporišič in (1975) quotes Lenček (154) and defines the 8 Slovene vowel phonemes also in Jakobson's terms (195). Our analysis, with one exception, is based on Chomsky and Halle $(1968,293-329)$ where, by and large, Jakobson's acoustically orientated features were replaced by articulatorily orientated features. Not all features, however, are exact equivalents of the distinctive features set up by Jakobson et alt.

In Slovene voicing plays a much greater role than in English in distinguishing the homorganic stop, affricate and fricative pairs. Chomsky and Halle considered the tense-lax opposition (324-325) operative in English, where voicing was only a possible accompanying feature. Delattre found that in English vocal cord vibration was only one - and that a less important one - of the six features distinguishing the co-called "voiced" from the "voiceless" sounds $(1965,113-118)$. As cover terms for both sets of features, we use the terms tenuis-media from Latin linguistics (Nemser 1971, 38).

1 The author wishes to record her indebtedness to Prof. William J. Nemser for the assistance he so generously gave her, and to Prof. Janez Orešnik for reading the article and suggesting some additions. - All the errors are the author's. I should also like to thank Prof. Margaret Davis for correcting my English. 
Table 1 - Slovene consonant phonemes

\begin{tabular}{|c|c|c|c|c|c|c|c|c|c|c|c|c|c|c|c|c|c|c|c|c|c|c|}
\hline & $\mathrm{p}$ & $\mathrm{b}$ & $\mathrm{t}$ & d & k & $\mathrm{g}$ & $\mathrm{c}$ & $\check{c}$ & j & $f$ & $\mathbf{s}$ & $\mathrm{z}$ & $\breve{s}$ & $\check{z}$ & $\mathrm{x}$ & $\mathrm{v}$ & 1 & $\mathrm{r}$ & $\mathbf{j}$ & $\mathrm{m}$ & $\eta$ & \\
\hline 1 son & - & - & - & - & - & - & - & - & - & - & - & - & - & - & - & + & + & + & + & + & + & \\
\hline $2 \mathrm{int}$ & + & + & + & + & + & + & + & + & + & - & - & - & - & - & - & & & & & & & \\
\hline 3 str & - & - & - & - & - & - & + & + & + & - & + & + & + & + & - & & & & & & & \\
\hline 4 ant & + & + & + & + & - & - & + & - & - & + & + & + & - & - & - & + & $(+$ & $+)$ & - & $(+$ & $+)$ & \\
\hline 5 cor & - & - & + & + & $(-$ & - & + & + & + & - & + & + & + & + & $-)$ & - & + & + & - & - & + & \\
\hline 6 ten & + & - & + & - & + & - & 0 & + & - & 0 & + & - & + & - & 0 & & & & & & & \\
\hline & & & & & & & & & & & & & & & & - & $\bar{t}$ & - & - & + & + & $\begin{array}{l}\text { nas } 7 \\
\text { lat } 8\end{array}$ \\
\hline
\end{tabular}

Table 2 - English consonant phonemes

\begin{tabular}{|c|c|c|c|c|c|c|c|c|c|c|c|c|c|c|c|c|c|c|c|c|c|c|c|c|}
\hline & $\mathrm{p}$ & b & $t$ & d & $\mathrm{k}$ & $\mathrm{g}$ & $\check{c}$ & ju & f & $v$ & $\theta$ & $\partial$ & s & $\mathrm{z}$ & $\breve{s}$ & $\check{\mathbf{z}}$ & h & 1 & $\mathbf{r}$ & $\mathbf{j}$ & $\mathbf{w}$ & $\mathrm{m}$ & $\mathbf{n}$ & $\eta$ \\
\hline 1 son & - & - & - & - & - & - & - & - & - & - & - & - & - & - & - & - & - & + & + & + & + & + & + & + \\
\hline $2 \mathrm{int}$ & + & + & + & + & + & + & + & + & - & - & - & - & - & - & - & - & - & & & & & & & \\
\hline $3 \mathrm{str}$ & - & - & - & - & - & - & + & + & - & - & - & - & + & + & + & + & -1 & & & & & & & \\
\hline 4 ant & + & + & + & + & - & - & $(-$ & $-)$ & + & + & + & + & + & + & - & - & - & $(+$ & t) & - & - & + & $(+)$ & - \\
\hline 5 cor & - & - & + & + & $(-$ & $-)$ & $(+$ & $+)$ & - & - & + & + & $(+$ & $+)$ & $(+$ & $+)$ & $(-)$ & + & + & - & - & - & + & - \\
\hline 6 ten & + & - & + & - & + & - & + & - & + & - & + & - & + & - & + & - & 0 & & & & & & & \\
\hline & & & & & & & & & & & & & & & & & & + & - & & + & + & & $\begin{array}{c}+ \text { nas } 7 \\
\text { lat } 8 \\
\text { bk } 9\end{array}$ \\
\hline
\end{tabular}




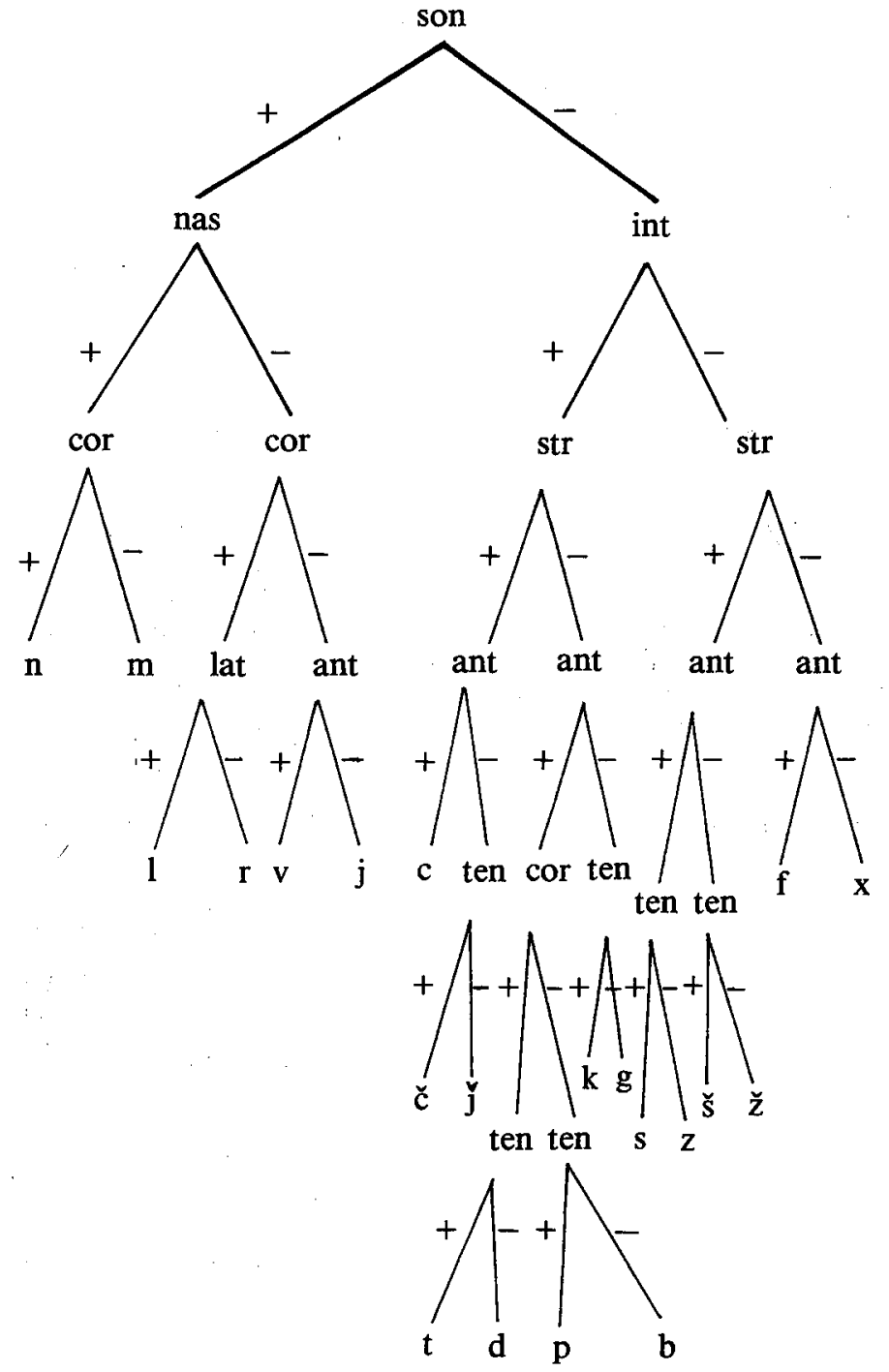

Fig. 1 - Slovene consonant phonemes

The Slovene matrix and tree diagram. The tree diagram tries to follow phonetic criteria as strictly as possible. All the consonants are divided into obstruents and sonorants. The feature interrupted divides the obstruents into plosives and fricatives. Stridency separates the affricates from the plosives proper. The diagram shows the weakness of the two features anterior and coronal, they both specify the same thing, i. e. the place of articulation. Sometimes one alone, and sometimes both are necess- 


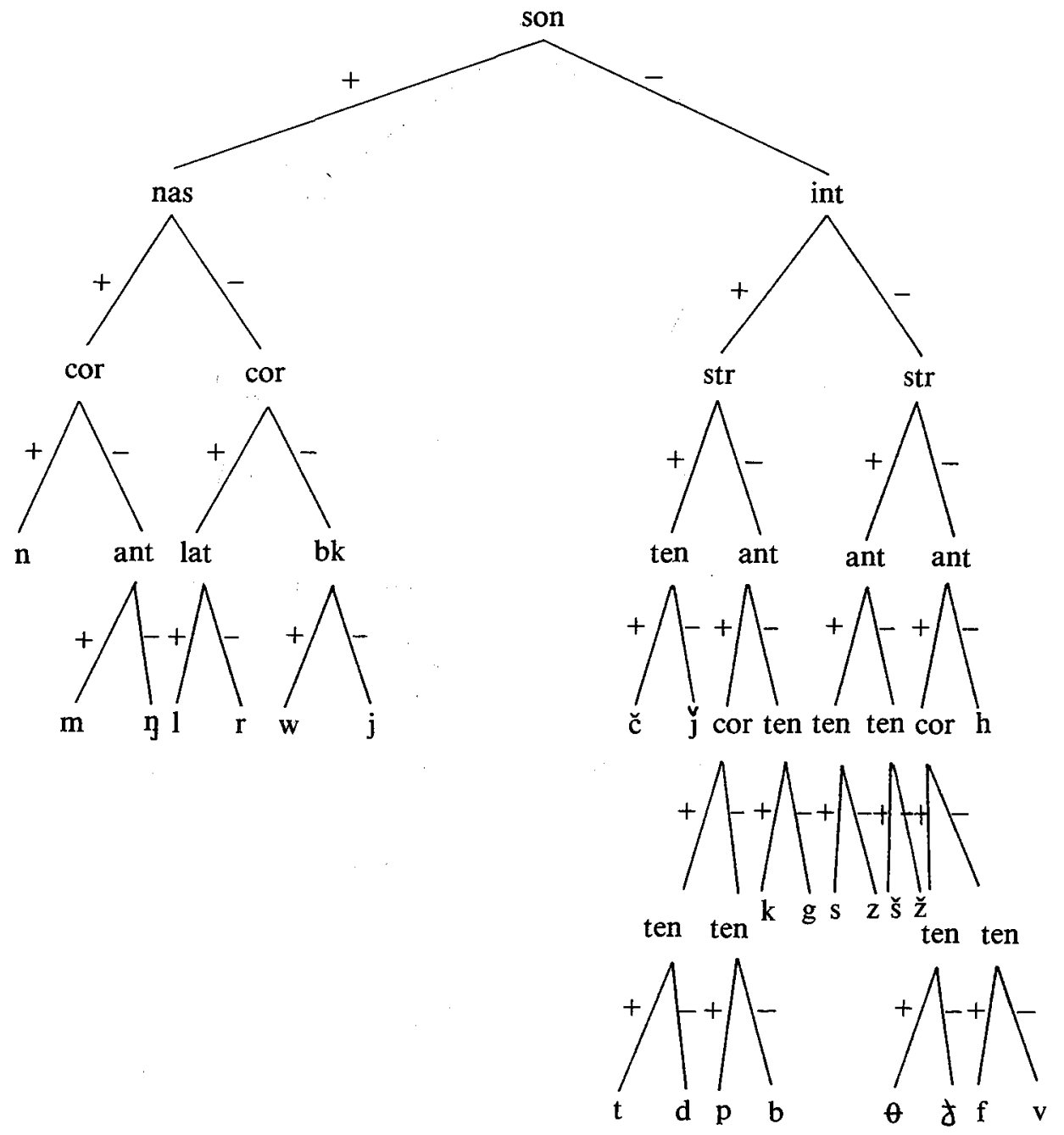

Fig. 2 - English consonant phonemes

ary to specify the place of articulation of a phoneme. All phonemes can make use of both. However, both of them may not always be needed to define a phoneme, to distinguish it from any other phoneme in the system (See redundancy 4). Anterior and coronal are indicated in the matrix - although in brackets - as we think them necessary to achieve phonetic realism.

Thus all the obstruents are specified as to anteriority and the feature coronal is necessary only to distinguish the anterior phonemes $/ \mathrm{p} /, / \mathrm{b} /$ from the anterior $/ \mathrm{t} /$, 
$/ \mathrm{d} /$. With sonorants however, [ \pm cor] divides the non-nasals into the two natural groups $1 / \mathrm{r}$ and $\mathrm{v} / \mathrm{j}$, with the feature [ \pm lat] distinguishing $/ 1 /$ from $/ \mathrm{r} /$, and $[ \pm$ ant] $/ \mathrm{v} /$ from $/ \mathrm{j} / .[+\mathrm{str}]$ distinguishes the sibilants from the other fricatives and $[+$ ant] separates $s / z$ from $\breve{s} / z$ and $/ f /$ from $/ x /$.

The order of application of the features is consistent within the two groups of obstruents and sonorants but not within the consonants as such. It was thus necessary to apply feature cor before the feature ant within the sonorants, and the feature ant before cor with obstruents. As we mentioned earlier, they both really specify the same thing.

Number of features. Eight features in all. [ \pm son] divides them into obstruents/sonorants. Obstruents are specified by the five additional features interrupted, strident, anterior, coronal, tenuis. And sonorants are specified by four more features anterior, coronal, nasal and lateral.

Obstruents are specified by $4-6$ features and sonorants by $3-4$.

The matrix brings out the dual character (function) of Slovene [v] and thus breaks the biuniqueness principle. We put /v/ among the sonorants following Toporišič's theory (Toporišič, 1984, 67). He considers /v/ a sonorant because it can - like other sonorants - combine into clusters with voiced as well as voiceless obstruents (e. g. dvojen - tvoj). In our analysis /f/ in the obstruent group has no voiceless counterpart, and so voice is nondistinctive with $/ f /$. This reflects the actual state of affairs: /f/ has a voiced allophone before voiced obstruents (e. g. grof gre), it can be voiced or voiceless, depending on its surroundings. If we had put $/ \mathrm{v} /$ among the obstruents, as older Slovene grammarians did, /f/ would have had a voiced counterpart, the biuniqueness principle would not have been broken, but the function of $/ v /$ in the Slovene system of sounds would have been blurred.

The English tree diagram and matrix. Though the Slav assimilation rule concerning voice which divides the Slovene consonants into two big groups - into the one where this assimilation is active (= nonsonorants, obstruents) and into the one where it is not (= sonorants) - does not apply in English, the two languages have a highly similar syllable structure with a similar distribution of obstruents and sonorants within the syllable, so that this division does not seem unnatural in the English language.

The distinctive features that distinguish obstruents are the same in both languages and are applied in the same order in English as in Slovene.

[ cates from the plosives proper and the fricative sibilants from the fricative nonsibilants. [ \pm ant] and [ \pm cor] (where necessary) specificy them as to their place of articulation and [ \pm ten] distinguishes the fortis/lenis pairs of obstruents. 
Nasality separates the nasals from the other sonorants, laterality divides $/ 1 /$ from $/ \mathrm{r} /$. As $/ \mathrm{w} /$ and $/ \mathrm{j} /$ are both [- cor] and [- ant], a new feature back had to be introduced here to distinguish the two sounds. In Slovene this feature is not necessary as $/ \mathrm{v} /$ has the function of English $/ \mathrm{w} /, \mathrm{v} /$ being [ + ant] and $/ \mathrm{j} /$ [- ant $]$. If we considered lip-rounding distinctive in English and not tongue position, then we could do without the feature back, English $/ w /$ would then be $[+$ ant $]$ and $/ j /[-$ ant]. - The back feature could have been applied to all other consonants, but it would always be redundant. (type 4 redundancy).

\section{REDUNDANCY}

\section{Different types of redundancy}

1. ${ }^{2}$ A feature is implied in another feature class. E. g. all Slovene and English sonorants are automatically [ - int] (blank space in the 2 matrices after the bar);

2. A feature is absent a) in a whole class. E. g. Slovene and English sonorants have nothing to do with stridency. Slovene and English obstruents have nothing to do with nas and lat (blank space in the 2 matrices after the bar). b) A feature is absent in a group of phonemes. E. g. lat in Slovene and English distinguishes the liquid $/ 1 /$ from the liquid $/ r /$ in the sonorant row. The other sonorants have nothing to do with laterality (blank space in the matrices);

3. ${ }^{2}$ A phoneme may be either + or - a certain feature. This e.g. applies to Slovene $/ \mathrm{c} /, \mathrm{x} /$, and $/ \mathrm{f} /$ which all have voiced allophones in Slovene, and to English /h/ which can be partially voiced (Gimson 1980, 191) (marked 0 in the 2 matrices). The voiced allophone of Slovene / $\mathrm{f} /$ thus coincides phonetically with the sonorant /v/ (see also p. 51). In the 2 matrices the Slovene and English sonorants are not absolutely barred from the ten feature as their allophones may be partially devoiced. On the phonetic level there may be partial devoicing;

4) A feature is present either in its + or - form. There are, however, enough other features to distinguish the phoneme. E. g. in the Slovene matrix the cor row from $/ \mathrm{k} /$ to $/ \mathrm{x} /$ is in brackets. In English cor with some obstruents. All the redundancies in the Slovene vowel system.

2 These 2 types of redundancy are mentioned in Muljačic 1972, 110. 
Table 3 - Slovene vowel phonemes

\begin{tabular}{lcccccccc}
\hline & $\mathrm{i}$ & $\mathrm{e}$ & $\varepsilon$ & $\mathrm{a}$ & $\jmath$ & $\mathrm{o}$ & $\mathrm{u}$ & $\partial$ \\
\hline 1 high & + & + & - & - & - & + & + & - \\
2 mid & - & + & + & - & + & + & - & + \\
3 back & - & - & - & $(+)$ & + & + & + & + \\
4 rounded $(-)$ & $(-)$ & $(-)$ & $(-)$ & + & $(+)$ & $(+)$ & - \\
\hline
\end{tabular}

Table 4 - English vowel phonemes

\begin{tabular}{lccccccccccc}
\hline & $\mathrm{i}$ & $\mathrm{I}$ & $\mathrm{e}$ & $æ$ & $a$ & 0 & $\mathrm{o}$ & v & $\mathrm{u}$ & $\wedge$ & $\partial$ \\
\hline 1 high & + & + & - & - & - & - & - & + & + & - & - \\
2 mid & - & + & + & - & - & - & + & + & - & - & + \\
3 back & - & - & - & - & + & + & + & + & + & + & + \\
4 rounded $(-)$ & $(-)$ & $(-)$ & $(-)$ & - & + & + & $(+)$ & $(+)$ & - & - \\
5 tense & $(+)$ & $(-)$ & $(-)$ & $(-)$ & + & $(-)$ & $(+)$ & $(-)$ & $(+)$ & - & 0 \\
\hline
\end{tabular}

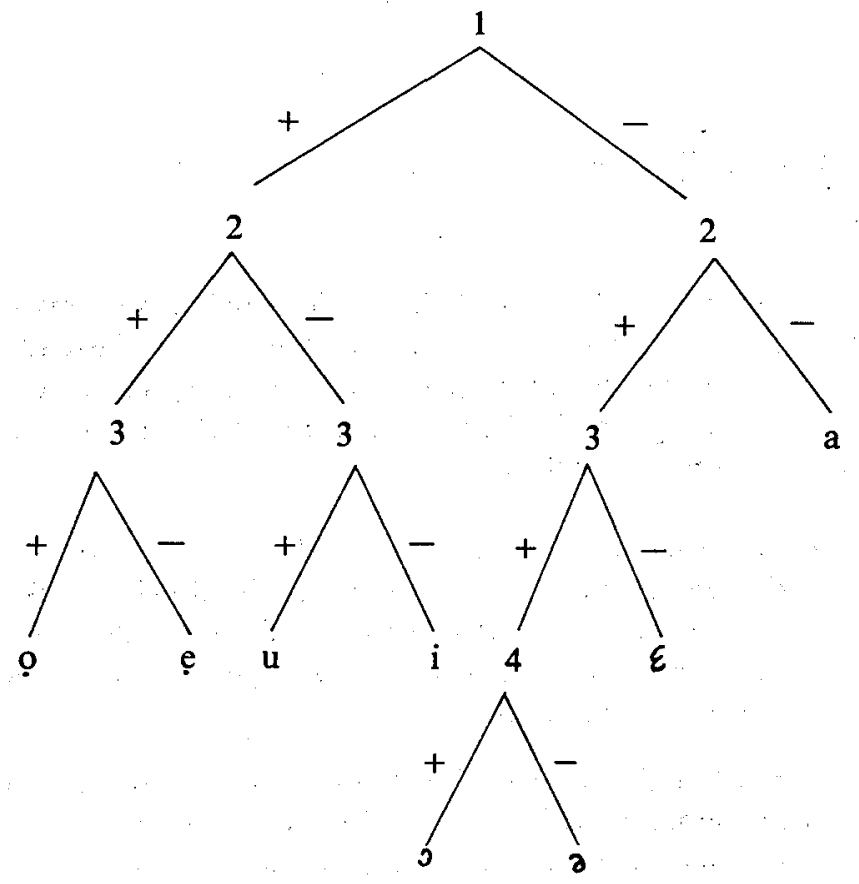

Fig. 3 - Slovene vowel phonemes 


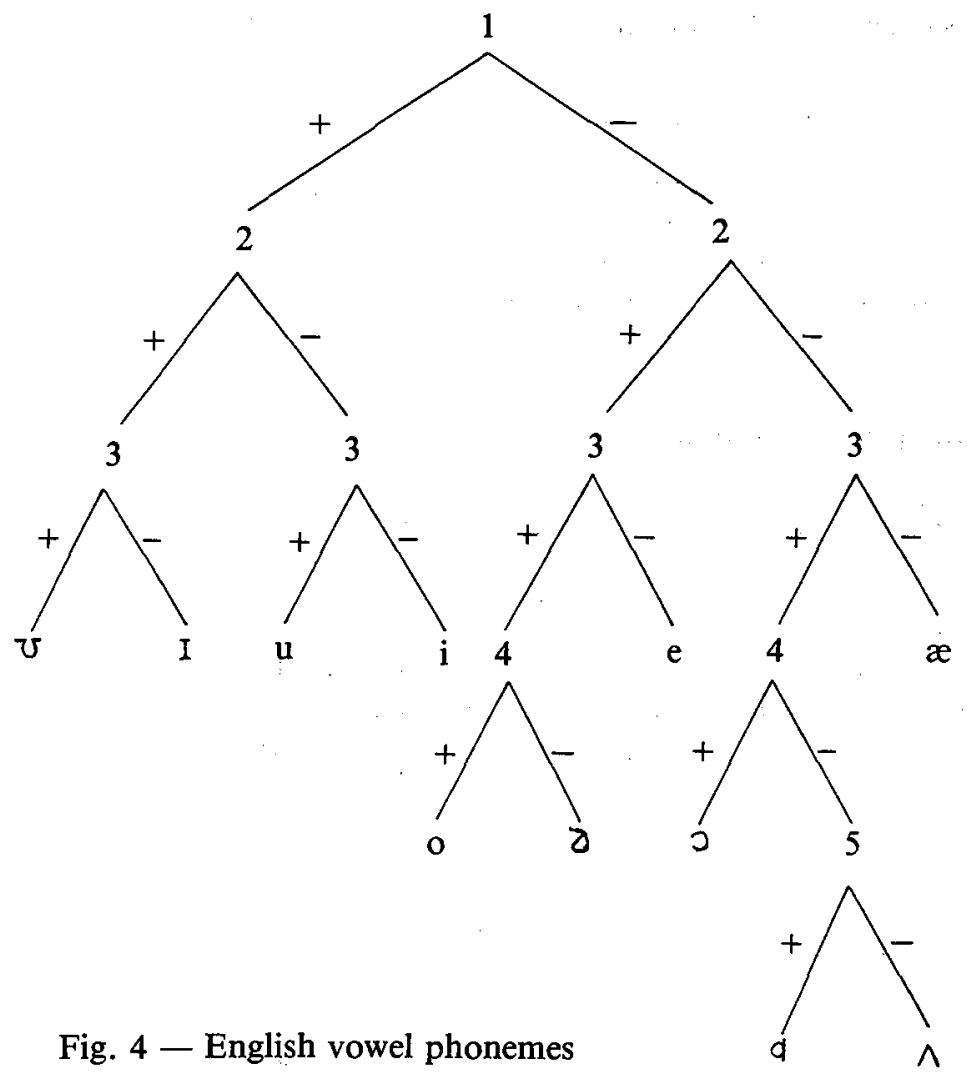

The Slovene vowel system has four heights. Four-height systems are generally handled with the features [ \pm high] and [ \pm mid] (Wang, 1968) instead of [ \pm high] and [ \pm low], which allow for only three degrees of openness as a vowel cannot be at the same time $[+$ low] and $[+$ high]. The two features high and mid, however, can co-occur as a vowel can be $[+$ high $]$ and $[+$ mid $]$.

The Slovene eight vowel phonemes can be specified with the four features high, mid, back and round. Central and back vowels are specified as [ + back]. [ \pm round] divides them into two groups. [ - back] vowels are all redundantly [- round]. As there are only eight vowel phonemes in Slovene these four features suffice to specify phonologically all Slovene vowel phonemes.

According to traditional grammar (Toporišič, 1984, 52) these eight phonemes can have the following phonetic realizations: With the exception of $/ e /$ and $/ 0 /$ they can all occur in unstressed position where they are always short, /e / and /o/ are only long and can occur only in a stressed syllable. $/ \partial /$, on the other hand, whether stressed or unstressed, is always short. The other vowels, i.e. $/ \mathrm{i}, \varepsilon, \mathrm{a}, \mathrm{o}, \mathrm{u} / \mathrm{when}$ 
stressed can be either short or long. In a stressed non final syllable they are long. In a final syllable or in a monosyllabic word, when stressed, they can be either short or long. This is the only position in which we can theoretically expect minimal pairs with length as the only distinctive feature. We can find such minimal pairs, though very few, only with the vowels /i, a, u/; e.g. [sit] - [si:t] (adj. full - noun gen. pl. sieves), [brat] - [bra:t] (noun nom. sg. brother - verb supine to pick) [kup] [ku:p] (noun pile - noun purchase). There can be no minimal pairs containing /ẹ/, $/ \mathrm{g} /$ as these can be only long. There are no minimal pairs containing long and short $/ E /$ or $/ 0 /$. With the mid vowels there are no minimal pairs with quantitative oppositions. As already mentioned, there are very few minimal pairs in Slovene, and the members of the pair generally occur in different distribution.

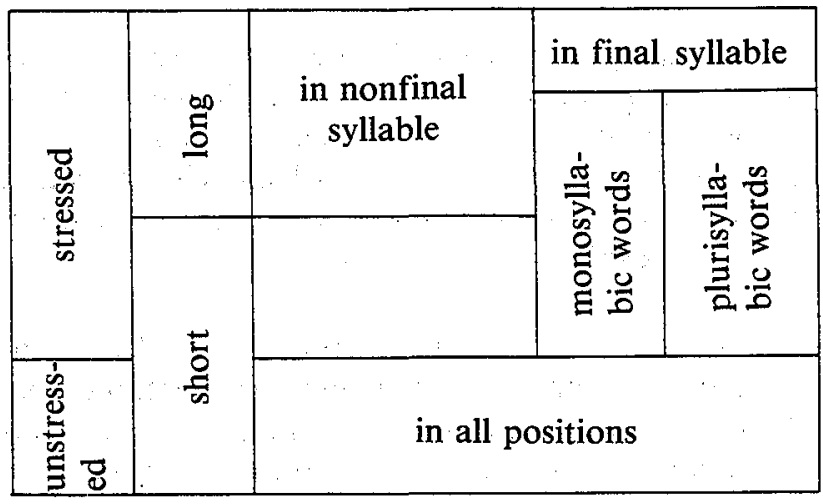

$\rightarrow$ to be read from left to right.

Fig. 5 - Quantity of Slovene vowels $/ \mathrm{i}, \mathrm{u}, \varepsilon, \supset, \mathrm{a} / \mathrm{according}$ to traditional grammar of SS

Our analysis deviates from the prescribed Slovene vowel system valid for Standard Slovene as presented in fig. 5. In the traditional vowel system, length is phonologically relevant as it can be either long or short in a stressed final or only syllable.

An acoustic investigation of vowel duration, however, has shown that speakers of Standard Slovene as spoken in Ljubljana do not observe the dinstinction between stressed long and stressed short vowels in a final syllable (Srebot Rejec, 1987, $247-260$ ). Length is not phonologically relevant, but only stress. The picture that emerges from this study is: the two close vowels /e/ and /o/ can appear only in stressed position, and are therefore always long. All the other vowels $/ i, \varepsilon, a, 0, u$, a / can occur in either stressed or unstressed position and can be either long or short, depending on whether they are stressed or not.

Every speaker of Standard Slovene, however, is well aware of the distinction 
between stressed $/ \mathrm{e} /-/ \varepsilon /$, and between stressed $/ o /-/ 3 /$ as there are a number of minimal pairs of this type. Here it is quality that is distinctive, e.g. 'pẹta - 'p $\varepsilon$ ta (p. part. fem. sing - noun heel), 'mora - 'm $\supset$ ra (3rd pers. sg. pres.t. must noun nightmare). Lenček $(1966,7 ; 1982,163)$ considers tenseness as the distinctive feature between $/ e /-/ \varepsilon /$, and $/ o /-/ \rho /$. In our opinion we have not to do with tenseness here because a) all 4 vowel phonemes are long when stressed, b) the two front vowels do not differ in the degree of frontness. Both are peripheral. The fact that $/ \epsilon /$ and $/ \supset /$ are more open than $/ e /$ and $/ o /$ is not reason enough to consider the former two lax in the latter two tense; neither is the fact that we can have morphonemic alternations between stressed $/ \mathrm{e} / \mathrm{-}-\mathrm{\varepsilon} / \mathrm{f}$, and $/ \mathrm{o} /-/ \mathrm{o} / \mathrm{e}$, $\mathrm{g}$. $[\mathrm{km} \varepsilon \mathrm{t}]$ - ['kmeta], [p J r $\circ \mathrm{t}]$ - [p o'roda], as we can have instances with no alternations as well, e. g. [šp $\left.\varepsilon \mathrm{x}]-[\mathrm{s} p \varepsilon \mathrm{xa}],\left[\mathrm{p} \jmath^{\prime} \mathrm{r} \supset \mathrm{t}\right]-[\mathrm{p} \jmath \mathrm{r}\lrcorner \mathrm{da}\right]$.

In our phonemic analysis of English vowels we followed Gimson (1980, 90-91), but considered quality distinctive rather than length (idem. 94, 96). That is why the English vowels on the phonemic level have no length mark, and we have only one representative of the pair $/ a: /-/ \delta /$, which differ only in length and not in quality. $/ \partial /$ moreover stands apart from all the other pure vowels in that it can occur only in unstressed position.

Five features (high, mid, back, round, tense) are needed to specify these 11 phonemes. There are no redundancies in the first three features, roundness distinguishes fully back vowels from central vowels and $/ \alpha /$, and the tenseness feature,

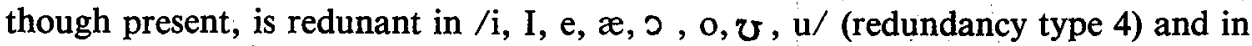
$/ \partial /$ (redundancy type 3).

In the English vowel system tenseness is a quality that covers the three dimensions length, degree of openness and peripherality (Jones, 1960, 39; Jakobson and Halle, 1969, 57-61). It neatly covers the differences between $/ \mathrm{i} /-/ \mathrm{I} /$ and $/ \mho /$ $/ \mathrm{u} /$ in all these three dimensions, that between $/ o /-/ \mathrm{o} /$ in length and degree of openness, but not in peripherality, as they are both fully back, while it does not work so well with the other RP vowels. Long / $a$ / differs from the supposedly lax

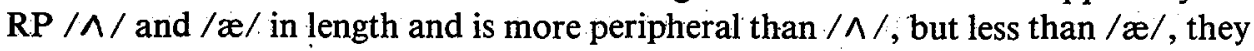
are, however, both closer than the supposedly tense $/ \alpha /$.

The relationships between the phonemes in the two systems, Slovene and English, can also be shown in the form of a chart that has an articulatory phonetic basis (Tables 5 and 6); or the two consonant systems only in a three-dimensional figure where the horizontal axis denotes the place of articulation, the vertical axis the manner of articulation, and the depth axis the tenuis-media distinction (Figures 6 and 7). 
Table 5 - Chart of Slovene sound system

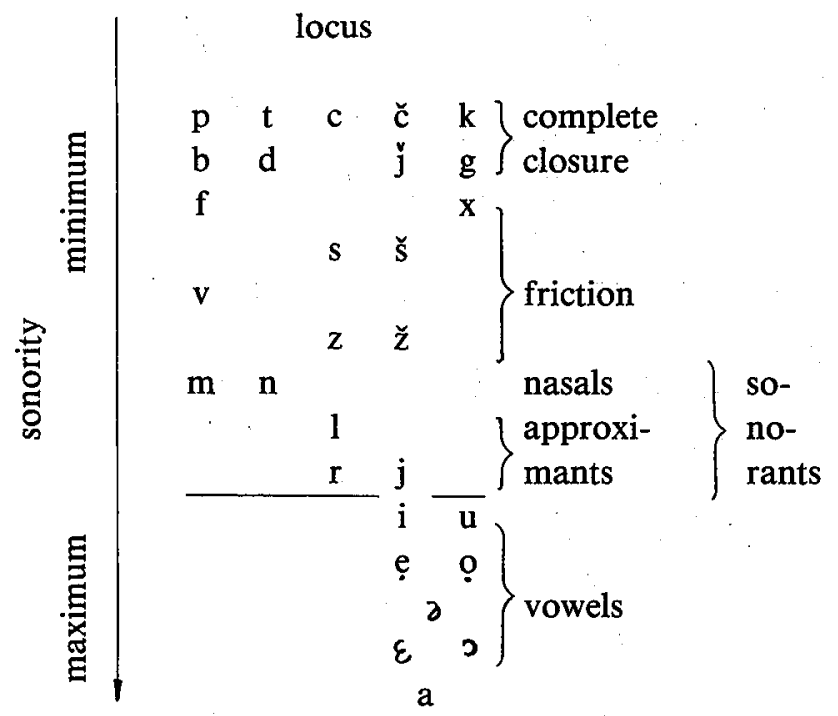

Table 6 - Chart of English sound system

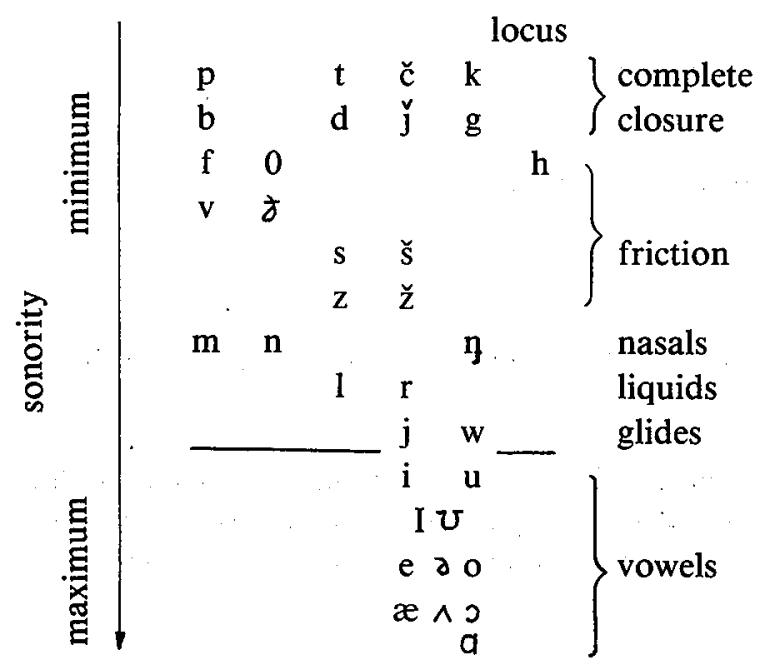

English has 24 consonant phonemes, Slovene 21. English has $/ \theta /, / d /$, and $/ \eta /$, which have no countterpart in Slovene, and Slovene has $/ c /$ with no counterpart in English. Slovene / $/$ occupies the space in the matrix of the combined fea- 


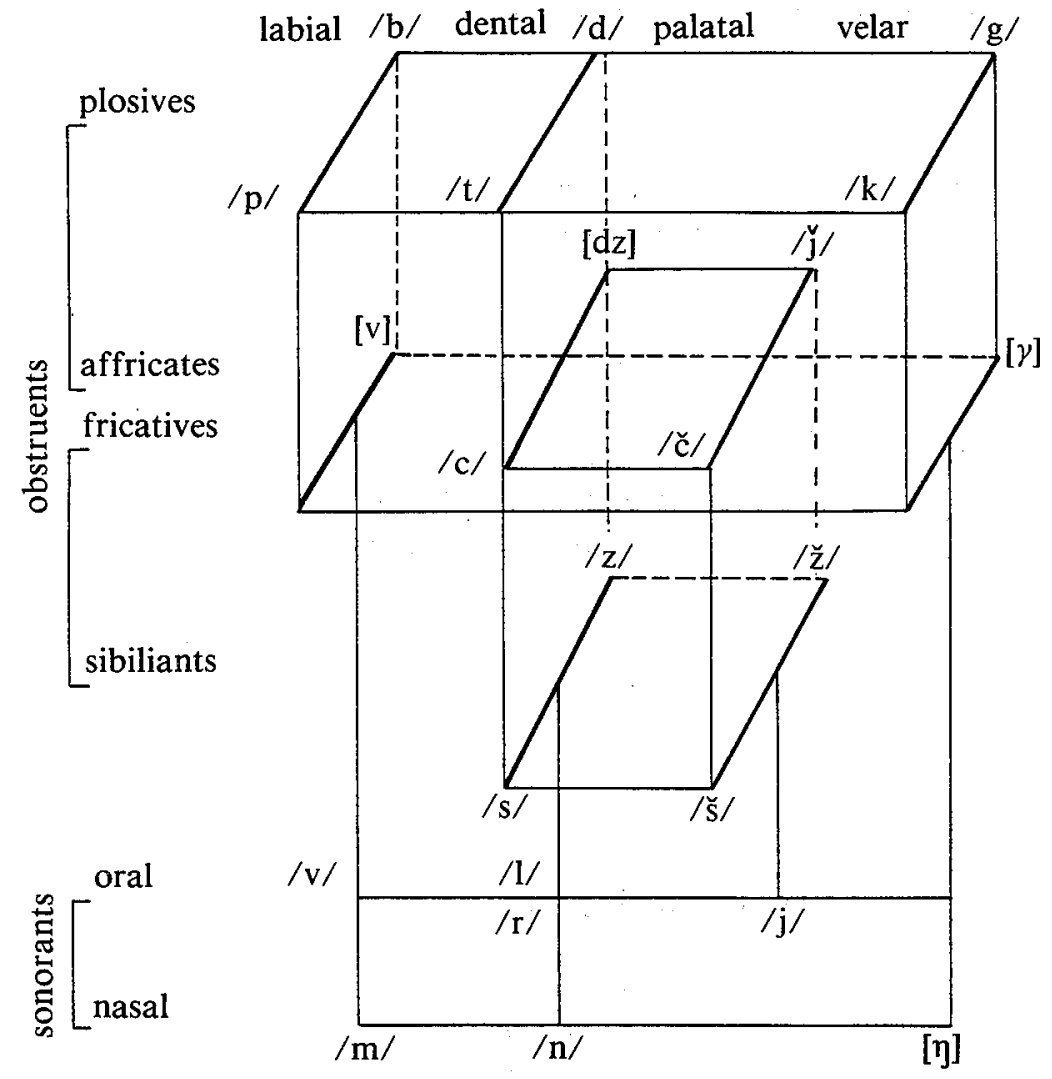

Fig. 6 - Slovene consonant system

tures of English /v/ and /w/, all the other consonants can be compared in the two languages.

The same distinctive features characterize both consonantal systems phonologically. The same groups of sounds are affected by the differing phonological rules in the two languages. The differences in the two consonant systems are thus concentrated on the phonetic level.

English has 11 vowel phonemes, and Slovene 8. English has two kinds of i-, u-, and a- phonemes, while Slovene does not. The two pairs of mid-vowel phonemes

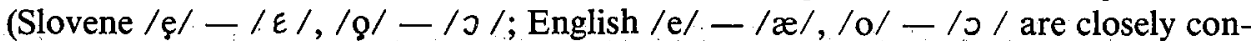
nected in Slovene but not in English. That is why they are not called mid-vowels in English. 


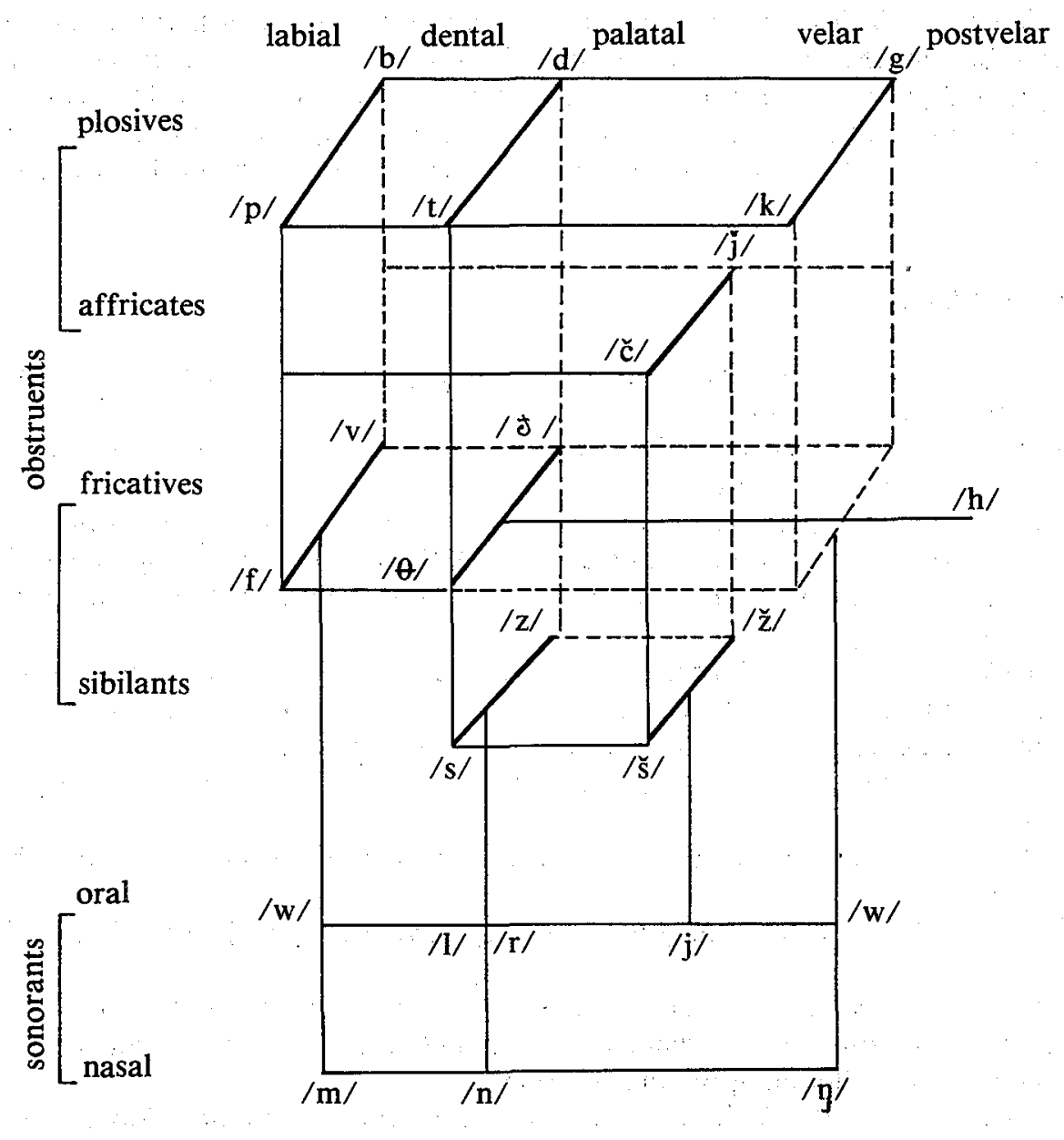

Fig. 7 - English consonant system according to Havranek, 1979, 104)

The two vowel systems have the same distinctive features from 1 to 4 , to which in English one feature is added (tense) to classify the more numerous English vowel phonemes. The differences between the two vowel systems are striking already on the phonological level. In English the tense feature is a cover term for different vowel features including length. In Slovene length is primarily stress dependent. There are 3 tongue heights in the English vowel system, according to Chomsky and Halle (1968), and 4 in the Slovene one. This holds only for stressed vowels. In unstressed position neutralisation of mid-vowels takes place in Slovene and there are then only 3 tongue heights. Stress does not play anything like such a role in English 
as in Slovene. All English vowels can occur both in stressed or unstressed position, while in Slovene the vowel quality of the mid-vowels can be stress dependent. In the Slovene mid-pairs morphophonemic alternation is common, quite a few words in Standard Slovene have variant pronuncations, either with the open or close midvowel. These vowels are also more prone to dialect variation than other vowels.

\section{REFERENCES}

Chomsky, N., and Halle, M., 1968, The sound pattern of English. New York, Evanston and London.

Delattre, P., 1965, Comparing the phonetic features of English, French, German and Spanish. Heidelberg.

Gimson, A. C., 1980, An introduction to the pronuncation of English. London.

Jakobson, R., Fant, C. G. M., and Halle, M., 1952, Preliminaries to speech analysis. The distinctive features and their correlates. (9th printing 1969). Cambridge Mass.

Havranek, G., 1979, Die Wahrnehmung der Tenuis/Media-Opposition im Englischen durch Kärntner Schüler. James A. and Kettemann B. (eds.), Dialektphonologie und Fremdsprachenewerb, 94-135. Tübingen.

Lenček, R. L., 1966, The verb pattern of Contemporary Standard Slovene. Wiesbaden.

Lenček, R. L., 1982, The structure and history of the Slovene language. Columbus Ohio.

Muljačić, Ž., 1972, Opča fonologija i fonologija suvremenog talijanskog jezika. Zagreb.

Nemser, W. J., 1971, An experimental study of phonological interference in the English of Hungarians. Indiana University publications Uralic and altaic series. Volume 105. Bloomington and the Hague.

Srebot Rejec, T., 1987, Word accent and vowel duration in Standard Slovene. (An acoustic and linguistic investigation). Celovec-Klagenfurt. (unpubl. Ph. D. dissertation).

Toporišič, J., 1975, Formanti slovenskega knjižnega jezika. Slavistična revija, 23, $153-196$.

Toporišič, J., 1984, Slovenska slovnica. Maribor. 


\section{Povzetek}

\section{GLASOVNA SESTAVA ANGLEŠČINE IN SLOVENŠČINE TER RAZLOČEVALNA OBELEŽJA V OBEH JEZIKIH}

Razprava poskuša ugotoviti, kako razločevalne fonetične lastnosti soglasnǐ̌kega in samoglasniškega sestava delujejo $v$ sloven ščini in $v$ angleščini. Razločevalna obeležja so v obeh sestavih ista, kolikor je to pač mogoče, ne da bi se pri tem delala sila glasovnemu sestavu obeh jezikov. Pri tem uporabljamo obeležja, kot sta jih postavila Chomsky in Halle. Sestavi razločevalnih obeležij so podani v obliki tabel (Tabele $1-4$ ) in v obliki dreves (Črteži $1-4$ ). Tabeli 5 in 6 prikazujeta razvrstitev glasov v obeh jezikih po zvočni polnosti, črteža 6 in 7 pa tridimenzionalno razvrstitev soglasnikov, kjer predstavlja vodoravna os mesto artikulacije, navpična način artikulacije in globinska os zvenečnost.

$V$ slovenščini je 21 soglasniških fonemov, v angleščini pa 24 . Angleščina ima $/ \theta /, /$ in $/ \mathrm{j} /$, ki nimajo ustreznih fonemov v slovenščini, slovenščina pa $/ \mathrm{c} /$, ki nima ustreznika $\mathrm{v}$ angleščini. Slovenski $/ \mathrm{v} /$ kombinira obeležja angleških fonemov $/ v /$ in /w/, vsi ostali soglasniki v obeh jezikih so primerljivi. Soglasniška sestava sta si na fonološki ravni podobna, fonološka pravila bi pa pokazala, da so razlike $v$ obeh sestavih predvsem na fonetični ravni.

Med slovenskim in angleškim vokalizmom se velike razlike že na fonološki ravni. Sestav slovenskih samoglasnikov, kot je tu predstavljen na podlagi akustične raziskave, se razlikuje od sestava, predpisanega za knjižno slovenščino. Dolžina samoglasnikov je odvisna od naglašenosti in vsi naglašeni samoglasniki so dolgi, medtem ko je v angleščini dolžina ena od sestavin napetega vokala. Vsi angleški samoglasniki lahko nastopajo $v$ naglašeni in $v$ nenaglašeni legi, $v$ sloven ̌̌čni pa nastopi v nenaglašeni legi nevtralizacija sredinskih samoglasnikov. V slovenščini je 8 samoglasniških fonemov, v angleščini 11 . Angleščina ima dve vrsti $i-j a, u-j a$ in a -ja, česar slovenščina nima. Sredinska slovenska para sta tesneje povezana, angleška pa ne. 